\title{
Third-quarter biotech job picture
}

\section{Michael Francisco}

$T_{\mathrm{p}}$

he third quarter of 2012 saw the number of advertised biotech and pharma sector jobs remain stable from the previous quarter (Nat. Biotechnol. 30, 803, 2012). On the representative job databases tracked by Nature Biotechnology, the number of total listings for the largest companies increased on Monster but declined on LinkedIn. Companywise, CSL, bioMérieux, PerkinElmer, IDEXX Laboratories, Celgene, Johnson \& Johnson and Roche substantially increased their numbers of open positions on at least one job board, whereas Monsanto, Amgen, Bio-Rad Laboratories, Biotest, Dendreon, Bayer, GSK, Pfizer and Merck experienced hiring slowdowns (Tables 1 and 2).

Notable expansions during the quarter include New Brunswick, New Jersey-based Johnson \& Johnson, which plans to establish four regional centers to identify and accelerate development of early-stage life science innovations. The centers will be located in California (with campuses in San Diego and San Francisco), Boston, London and an as-yet-undetermined location in China. Morphotek, a subsidiary of Eisai, will open an \$80-million, 60,000-square-foot biologics manufacturing facility in Exton, Pennsylvania. Covidien opened an R\&D facility in Shanghai, housing 17 laboratories and surgical suites and employing over 300 people. Finally, Amarillo Biosciences plans to open an operations center in Taipei, Taiwan, to explore new business opportunities in Asia.

\begin{tabular}{|c|c|c|c|c|}
\hline \multirow[b]{2}{*}{ Companya } & \multirow{2}{*}{$\begin{array}{l}\text { Number of } \\
\text { employees }\end{array}$} & \multicolumn{3}{|c|}{ Number of advertised openings ${ }^{b}$} \\
\hline & & Monster & Linkedln & Naturejobs \\
\hline Monsanto & 21,400 & 5 & 2 & 0 \\
\hline Amgen & 17,250 & 1 & 92 & 0 \\
\hline Life Technologies & 11,000 & 41 & 47 & 817 \\
\hline Genzyme & 10,100 & 94 & 41 & 0 \\
\hline CSL & 9,992 & 17 & 0 & 0 \\
\hline Bio-Rad Laboratories & 6,880 & 10 & 5 & 0 \\
\hline bioMérieux & 6,378 & 28 & 3 & 0 \\
\hline PerkinEImer & 6,200 & 69 & 9 & 0 \\
\hline Novozymes & 5,655 & 0 & 1 & 1 \\
\hline Biogen Idec & 4,850 & 33 & 36 & 2 \\
\hline IDEXX Laboratories & 4,800 & 31 & 6 & 0 \\
\hline Biocon & 4,478 & 0 & 0 & 0 \\
\hline WuXi AppTech & 4,465 & 0 & 8 & 0 \\
\hline Shire & 4,183 & 90 & 11 & 0 \\
\hline Celgene & 4,182 & 66 & 11 & 7 \\
\hline Gilead Sciences & 4,000 & 0 & 30 & 0 \\
\hline Cephalon & 3,726 & 0 & 0 & 0 \\
\hline Qiagen & 3,587 & 0 & 1 & 0 \\
\hline Endo Pharmaceuticals & 2,947 & 0 & 18 & 0 \\
\hline Actelion & 2,441 & 5 & 4 & 0 \\
\hline Illumina & 2,100 & 35 & 13 & 35 \\
\hline Vertex Pharmaceuticals & 1,691 & 28 & 10 & 1 \\
\hline Biotest Pharmaceuticals & 1,627 & 0 & 1 & 0 \\
\hline Dendreon & 1,497 & 0 & 2 & 0 \\
\hline Albany Molecular Research & 1,421 & 0 & 0 & 0 \\
\hline Total & & 557 & 351 & 863 \\
\hline
\end{tabular}

AstraZeneca announced that its subsidiary MedImmune will close two of its infectious disease and vaccine R\&D sites in Mountain View and Santa Clara, California, as part of the pharma company's broader restructuring program announced in the first quarter of 2012. The closures will reduce headcount by 200 and relocate an additional 100 positions to MedImmune's other facilities. Additionally, Boehringer Ingelheim said it will discontinue its virology research program, resulting in the loss of about 170 employees, due to the closure of a Laval, Quebec, research facility in early next year.

Other third-quarter downsizings of note within the life science industry are shown in Table 3.

\begin{tabular}{|c|c|c|c|c|}
\hline \multirow[b]{2}{*}{ Company $^{a}$} & \multirow{2}{*}{$\begin{array}{l}\text { Number of } \\
\text { employees }\end{array}$} & \multicolumn{3}{|c|}{ Number of advertised openings ${ }^{b}$} \\
\hline & & Monster & LinkedIn & Naturejobs \\
\hline Johnson \& Johnson & 119,200 & 777 & 35 & 0 \\
\hline Bayer & 106,200 & 15 & 10 & 7 \\
\hline GlaxoSmithKline & 103,483 & 6 & 6 & 6 \\
\hline Sanofi & 99,495 & 1 & 8 & 0 \\
\hline Novartis & 98,200 & 128 & 28 & 6 \\
\hline Pfizer & 86,600 & 0 & 85 & 3 \\
\hline Roche & 78,604 & 2 & 206 & 24 \\
\hline Abbott Laboratories & 68,697 & 10 & 0 & 1 \\
\hline AstraZeneca & 67,400 & 56 & 30 & 11 \\
\hline Merck \& Co. & 59,800 & 9 & 60 & 0 \\
\hline Total & & 1,004 & 468 & 58 \\
\hline
\end{tabular}

\begin{tabular}{|c|c|c|}
\hline Company & $\begin{array}{l}\text { Number of } \\
\text { employees cut }\end{array}$ & Details \\
\hline Actelion & Up to 135 & $\begin{array}{l}\text { Will cut about } 5 \% \text { of its approximately } 2,500 \text { employees as part } \\
\text { of a plan to reduce spending by refocusing R\&D activities on spe- } \\
\text { cialty areas. The cuts will affect } R \& D \text { and administration. }\end{array}$ \\
\hline $\begin{array}{l}\text { AMAG } \\
\text { Pharmaceuticals }\end{array}$ & 45 & $\begin{array}{l}\text { Will restructure and reduce headcount by } 26 \% \text { to about } 130 \\
\text { by year end to focus on advancing anemia drug Feraheme } \\
\text { (ferumoxytol) and expanding its portfolio with commercial-stage } \\
\text { products. }\end{array}$ \\
\hline $\begin{array}{l}\text { Biolnvent } \\
\text { International }\end{array}$ & 21 & $\begin{array}{l}\text { Will restructure and reduce headcount by } 24 \% \text { to } 68 \text { following its } \\
\text { June decision to discontinue development of TB- } 402 \text {, which is } \\
\text { expected to save } \$ 2.1 \text { million annually. }\end{array}$ \\
\hline $\begin{array}{l}\text { Infinity } \\
\text { Pharmaceuticals }\end{array}$ & 30 & $\begin{array}{l}\text { Reduced headcount by about } 20 \% \text { to } 160 \text { after it discontinued } \\
\text { development of cancer compound saridegib and terminated a deal } \\
\text { with Purdue Pharma and Mundipharma. }\end{array}$ \\
\hline Dendreon & 600 & $\begin{array}{l}\text { Will restructure and reduce headcount by } 40 \% \text {. It will close its } \\
\text { Morris Plains, NJ, manufacturing facility, which is one of three } \\
\text { facilities producing prostate cancer drug Provenge (sipuleucel-T), } \\
\text { the company's only drug on the market. }\end{array}$ \\
\hline $\begin{array}{l}\text { Pharming } \\
\text { Group }\end{array}$ & At least 20 & $\begin{array}{l}\text { Will restructure its Dutch operations and reduce headcount to } \\
\text { align resources to transition from a mainly internal research- } \\
\text { driven model to a market-driven, external R\&D model. }\end{array}$ \\
\hline QLT & 146 & $\begin{array}{l}\text { Will restructure and reduce headcount by } 68 \% \text { to } 68 \text { to focus on } \\
\text { ophthalmic candidate QLT091001. }\end{array}$ \\
\hline $\begin{array}{l}\text { Savient } \\
\text { Pharmaceuticals }\end{array}$ & 60 & $\begin{array}{l}\text { Will restructure and reduce headcount by about } 35 \% \text { to improve } \\
\text { operational efficiencies while focusing on the commercialization } \\
\text { of Krystexxa (pegloticase). }\end{array}$ \\
\hline
\end{tabular}

Michael Francisco is a Senior Editor at Nature Biotechnology. 